\title{
Labour Migration and Dislocation in India's Silicon Valley
}

Rebecca Bowers 1 ,* (iD)

1 Department of Anthropology, London School of Economics, London, United Kingdom

\section{Abstract}

The migrant families who build India's cities do so to meet practical and ritual aspirations rooted in the village, undergoing spatial and temporal fragmentation to maintain rural longevity and the possibilities of ritual time. This article contributes an alternative position to linear-framed presumptions of migration and urbanity, illustrating instead how everyday experiences of dislocation can be productive through labor, timespace, and imagination; bridging the gulf between residence on urban construction sites in Bengaluru, southern India, and desired village homes. However, lived experiences of dislocation remain stratified by gender and class, leading to highly conjugated experiences of precarity, mobility, and possibility. Despite the urban ambivalence felt by women and girls as a result, a shared experience of dislocation enables entire families to undertake the grueling yet regenerative work of circular migration, ensuring the continuation and renewal of village life and ritual time through its incompleteness.

\section{Keywords}

Labor Migration | Gender | Dislocation | Timespace | Construction Work

It was the Sunday of Ugadi when I visited the families living and working on Praveen's site, a four-story office block midway through completion. Ugadi, a Hindu festival, heralds the new year in the southern states of Andhra Pradesh and Karnataka, marking the day Lord Brahma created the universe. For those away from the village during Ugadi there were pangs of regret. While Ugadi is a principal and widespread celebration, on site the workers did not have the means with which to mark it, as Lingamma, attested; "[In the village] they make holige for the festival, but here there's no way to make those things." For families such as Lingamma's, working in Bengaluru provided a vital source of income. However, as a result, they missed many such occasions, as Lingamma elaborated; "Festivals come in abundance almost every month. But in Bangalore, we are completely unaware of festivals. We can't even realize the new moon day (Amavasya) here. But back in [the] village, we are aware of many festivals.

\section{Introduction}

The story of contemporary India has become undoubtedly urban, with forecasts predicting a near doubling of city populations by 2040 (see Agarwal 2020; UN 2018). There remains, 
however, a substantial portion of India's population that will never fully live in either rural or urban locales. While Indian cities have become equated with aspiration, global connectivity, and modernity (Dittrich 2007; Gopalan 2010; Khilnani 2012; Roy 2003), the Indian city also produces collective experiences of dislocation for migrant workers who inhabit liminal timespace on urban construction sites.

As the opening vignette reveals, for workers living in India's urban heartlands, temporal and ritual rhythms become fragmented, punctuated by absence. For my migrant interlocutors working in construction in Bengaluru, southern India, the rhythms of urban timespace are distinctively gendered - producing a divergence between how families inhabit the city and conceive of possible yet elusive futures. Dislocation as a spatial and imaginary process lies at the heart of such divergences. And yet, dislocation as a daily experience allows migrant families to maintain fragmented village lives and livelihoods through work in the city, while producing certain paradoxes of mobility.

Utilizing qualitative data from fieldwork conducted between October 2014 and May 2016 in Bengaluru, I illustrate how gendered, household, and family dynamics inform interlocutors' experiences of urban dislocation. This framing unsettles popular narratives of urban expansion and progress, including investor-oriented discourse promoting the myth of an urban "trickle-down" of wealth facilitated and generated by the growth of cities in India and the Global South (Alliance Experts; Consultancy UK 2017; McKinsey 2016). Significantly, it disrupts field-to-factory-to-service sector paradigms (Huang 2012; Pun and Huilin 2010) that continually inform development policy and fiscal restructuring projects, which themselves produce inequality and dislocation.

I consider dislocation as both a temporospatial process and imaginary; however, contrary to displacement as "an existential experience of contested temporal being, in which a person cannot reconcile the contemporary circumstances of their life with their aspirations for, and sense of, the future" (Ramsay, 2019, 389), I propose that dislocation proves fruitfulreconciling disruptive presents with unknowable futures. Dislocation, as a kinetic process and an imaginative act, is undertaken by groups and individuals, producing movement, affect, connection, and certain forms of aspiration. Dislocation upholds rural life, harnessing and mediating the liminality of migration to re-establish delayed ritual time (that is, the possibility of both transformation and renewal) in the village through the work of physical and imaginative labor. Dislocation circumnavigates the tension and "irreconcilability" (Ramsay 2019) between the present, futurity, and aspiration.

For families working in construction in Bengaluru, increasing spells spent within the city, delayed payment, and pausing education and ritual time dislocate possibilities of "progress" and aspiration associated with neoliberal, religious, and urban chronologies (Allison and Piot 2014; Bear 2015; Harms 2013; Srinivas 2018) while facilitating fragmented reunions with village timespace. In this context, "timespace" refers to "the means by which a particular sense of time comes into being and moves forward to frame our understandings and actions - [it] is in turn both multiple and dynamic" (May and Thrift 2001). Timespace may be understood through responses to timetables and rhythms (artificial and natural), systems of social discipline (secular and religious), relationships with instruments and devices (techne), and vehicles of temporal translation and regulation. I focus on the first two aspects of timespace, and how, while "Time thickens with ethical problems, impossible dilemmas, and difficult orchestrations" (Bear 2016, 489), temporospatial uncertainties are mediated and reconfigured through gendered subjectivities. 
The assumed relationship between aspiration and futurity is evident in Arjun Appadurai's conceptualization of the "capacity to aspire" $(2004,2013)$. This crucial quality for connecting pathways and networks with material and social desires, Appadurai argues, is diminished amongst the poor, who are constrained by scarcity, structural inequalities, and fatalism (2013, 188). I propose that migrant families on low incomes do not lack this form of imagination; rather their response to the uncertainty of life is informed by dislocation, rooted both in aspiration and practicality. Dislocation allows for both reconfiguration and prefiguration of fragmented timespace, making the unknowability of the future bearable and shaping it toward forms of village-based permanence - attempts to achieve stability and to endure through time and space into the next generation. While the preference of employers to maintain precarious workforces and scant livability in the city hinders spatial forms of permanence in Bengaluru, dislocation helps families negotiate the inhospitable cityscape to seek permanence in otherwise unsustainable rural homes.

In this article, I provide a contextual grounding of the construction workforce in the city and India, including specific conditions experienced by women. I then introduce the families of Hemavathi and Lingamma, before examining how they respond to dislocation by saving for desired village futures while suspending ritual and education time in Bengaluru. Exploring the gendered outcomes of dislocation on relationships with the city, I illustrate how subsequent discrepancies in experiences and imaginings of urban mobility inform timespace, consumption, and sentiment. The final section builds upon this, elucidating cross-cutting implications for children growing up on site, while iterating the ways in which construction work reinforces the stratification of social and gendered inequality. While a lack of productive urban networks and resources ensure dislocation for migrant families - especially women and girls - I conclude that dislocation facilitates resilience through spatial and conceptual peripherality, enabling a (disrupted) continuation of rural homesteads and lifecycles. I propose that an analysis of the "everydayness" of dislocation significantly enriches and adds nuance to our understandings of the rhythmic discord experienced within and facilitated by urban spaces and the life-worlds constructed within them.

\section{Building (Another) New Bengaluru}

Lauded as India's "city of the future" (Dittrich 2007, 46), the metropolis formerly known as Bangalore has experienced multiple identity shifts. Ranging from "garden city" to "pensioners' paradise," these vying narratives often incorporate a nostalgia for an idealized past alongside aspirational visions for the future. As Gopalan attests, "there was a throwback to a mythicized past, a longing for the pensioner's paradise and garden city of old [but] there was also an aspiration for a neoteric future, a Singapore in Bangalore" (2010, 2). Indeed, India's "Silicon Valley" has undergone rapid transformation since economic liberalization through enmeshed local and global processes of government policy, business outsourcing, and real estate speculation. The physical, temporal, and financial landscape of the city has been reshaped by political elites, aspiring real estate moguls, global investors, and a neoliberal boom in business outsourcing (Goldman 2011; Gopalan 2010).

Amidst this unfolding concrete backdrop, the superimposed imagery of smiling couples on real estate advertisements line urban roads and pavements, their looming faces serving as a reminder of lifestyles largely unattainable by its everyday populace. As if to obscure the city's vanishing flora and fauna, further attempts by real estate marketers to appeal to a limited audience of monied NRIs (Non Resident Indians) and high-ranking tech professionals 
can be witnessed via increasingly fanciful names of residential developments ("Oasis," "Palm Beach," "Lakeview"), water features, ice skating rinks, beach volleyball, and butterfly trails. Though the names, advertisements, and layouts of such developments evoke luxury and exclusivity, what lies beneath is not as pristine as it may appear.

Through the absorption of Bengaluru's real estate industry into global financial markets, the opacity and precarity produced by property speculation leaves developers under pressure to cut costs, build big, and sell fast. Fueling demand for a flexible workforce, such processes devolve the physical and financial risks onto workers, and frequent practices of risk devolution and profit maximization result in death, injury, and disease (Bangalore Mirror Bureau 2018; M.M. Rao 2019; Shruthi 2017). This high demand for migrant labor means that Bengaluru and its periphery host up to ten lakh (approximately one million) construction workers (Sriramakrishnan 2017; Ranganath 2019). A large portion are migrant workers from northern states; however, there remains a sizeable presence from the south, including northern Karnataka and neighboring Andhra Pradesh. The construction workforce is disproportionately composed of Dalit (scheduled caste) and Adivasi (scheduled tribe) workers $^{1}$ (Institute of Human Development 2014; Madhok 2005; Srivastava and Jha 2016), who remain overrepresented in the majority of India's manual and menial labor pool. Their lack of local citizenship rights makes migrant workers cheaper to hire, less visible, less likely to refuse dangerous working environments and overtime, and less likely to unionize (Pattenden 2012; RoyChowdhury 2014; A. Shah and Lerche 2020).

\section{Women workers in Bengaluru's construction industry: contextual analysis}

While cyclical rural-to-urban migration is historically rooted across India, women's labor migration to the south is rarer from northern states due to differing gender norms (Srivastava and Jha 2016; De Haan1999). Subsequently, the majority of the female construction workforce in Bengaluru consists of interstate and intrastate migrants from Karnataka and Andhra Pradesh, who travel as families. Though scholars have argued that a change of setting from the rigid patriarchal norms associated with village life may facilitate greater freedom (Dalmia 2012; Pun and Smith 2006; A. Shah 2006), construction site residence means women may in fact experience similar or higher limitations to their autonomy.

Despite regional variations, female labor contributes substantially to construction in Indiaconsistently one of the highest employers of women behind agriculture (Devi and Kiran 2013; Madhok 2005). The number of women undertaking construction work is between 30 to 50 percent (Devi and Kiran 2013; Khanijow 2018; Rahul 2014) of an estimated forty million workers (Bhalla 2015; Khanijow 2018; Salve 2013). There is, however, a dearth of reliable statistics, with women frequently undercounted in Labour Force Participation Rate surveys (A. Deshpande and Kabeer 2019).

Female workers endure discrimination industry wide. For migrant women, this is exacerbated by further restricted labor rights and residential conditions. Female workers are paid between a third to half the wages men receive for performing the same roles (see Devi and Kiran 2013; Bhalla 2015; WIEGO 2004), and are unable to ascend in the industry (Breman 2016; Parry 2014; Vaid 1999), making them susceptible to losing their jobsdeemed "unskilled" and superfluous in the wake of advancing technology (Baruah 2010). Less visible is the widespread and underreported sexual harassment and exploitation 
(particularly at the hands of employers) (Action Aid 2017; Parry 2014; Patel and Pitroda 2016). Accompanied by silence or blame, this continues to be informed by historical and ongoing classist and casteist discourse of working female bodies (Bear 2007; Chatterjee 1989; 1993; Parry 2014).

\section{Hemavathi and Lingamma's families}

Through Praveen, who owned a modestly sized real estate developer, I was able to access a medium-scale office construction project for six months in 2015-16. There I meet Hemavathi and Lingamma, their husbands and their children, who had traveled to Bengaluru from Kurnool, three hundred kilometers northeast across the border with Andhra Pradesh. Kurnool is one of the most underdeveloped regions in Andhra Pradesh (Express News Service 2018; Narain et al. 2009), and families from this area regularly migrate, undertaking gaare or coolie kelsa in Bengaluru, twelve hours away by bus. Reliant on mostly rain-fed irrigation, Kurnool has experienced worsening drought conditions and increased rates of farmer suicide (Reddy 2017, 2018; Sudhakar 2017).

When I began my visits to the office building under construction in Ramnagar, an up-andcoming former village in north Bengaluru, it was covered in a thicket of bamboo scaffolding. The building's bare concrete floors were strewn with detritus, its rough, unfinished walls haphazardly scribbled with chalk drawings. Hemavathi, her husband Basappa, and Rangamma and Shiva, their children, lived alongside Lingamma, her husband Suraj, and their children Eramma and Saubhagya, in small one-room breezeblock huts assembled from scavenged materials adjacent to the site. The huts were poorly ventilated and often choked with smoke from the cooking fire. In the summer months, tin roofs intensified the heat. Outside, piled against the hut walls was the rubbish dump for surrounding offices and apartments.

The remaining workers (around twenty when work was quieter) lived inside the incomplete building. Two families from northern Karnataka dwelled in blue tarpaulin tents on the ground floor, while the men from northern states resided upstairs, using tarpaulin as makeshift privacy screens. Throughout construction sites in India, worker accommodation is regionally and spatially designated (this is perceived to further prevent collective organization; see Parry 2014; Breman 1996), and the Ramnagar site was no different. The number of children between the four families on site fluctuated, though I grew accustomed to the company of Hemavathi and Lingamma's daughters, Rangamma and Eramma, who would follow my research assistant Aishwarya and I, singing and holding our hands, swinging younger children in tow. Moving from site to site with each new development, the families returned to their village whenever they could, although return was contingent on receiving wages, and on increasingly unreliable monsoons.

\section{Seeking Permanence Through Dislocation}

\section{Negotiating rural and urban uncertainty}

When I first met their families, Hemavathi and Lingamma had been working on Praveen's site for ten months. The women, both in their twenties, were unsure of their exact ages. Their husbands, cross-cousins, were not significantly older. Because of debt, both families sent 
nearly all their wages to the village, where relatives helped look after their small amount of land. There the families grew cotton, rice, and ahar (lentils). When there was little harvest, they worked the land of others. Their wages were not only critical in meeting immediate needs in the markedly more expensive city or various forms of ritual and lifecycle related to consumption but also to support village-based kin and pay off agricultural debts accumulated through spells of crop failure and drought. As Lingamma attested, the village was a place of scarcity: "We aren't left with even four rupees in the village, that's why we work here."

The lengthening spells the family spent in the city no longer reflected the seasons of the agrarian calendar but the failing rains, as Suraj, Lingamma's husband, explained: "We take loans while seeding the fields, but if there are no rains, there are no yields, the loan must be repaid." Harvest yields had become completely unpredictable, as confirmed by Shambhulingappa, a carpenter on site: "We got the yields as expected last time . . we got a gross income of between two to three lakhs [around two to three thousand pounds], but last year it didn't even touch one lakh." Since the monsoons had failed the prior year, Shambhulingappa had come to work in the city to support his wife and child back in the village. For those with less land and income, including Hemavathi and Lingamma's families, there was little choice but for the majority of the family to relocate.

In Bengaluru, where they held no ration cards and food prices were exponentially higher, existence for both families was frugal - little was spent on anything but food, essential toiletries, cooking oil, and alcohol for the men. Though occasionally Basappa or Suraj might return with a sweet for the children, or a plastic bangle for their daughters, money was never put toward the kinds of migrant material consumption and leisure expenditure associated with urban aspiration (Gamburd 2004; Jagori 2004; Mills 1997). However, maintaining this frugal lifestyle ensured that around half the money the families earned returned to the village. Such concerted acts of investment and fiscal discipline, while crucial to maintaining village life, reiterate the diminishing role of agricultural subsistence, which makes staying home no longer possible.

While "the popular account of metropolitan life is of one of increasing pace" urban timespace is increasingly conceptualized as being fragmented (Crang 2001, 188), simultaneously with and without promise (Ferguson 1999; Bunnell Gillen, and Ho 2017). Indeed, for Kemmer and Simone, "Cities function like promising machines, they give everyday life a rhythm, but as they constantly fail, they prompt residents to stand by and thus allow for other prospects, other 'minor' futures to pop up" $(2021,14)$. For Hemavathi and Lingamma's families, their residence in Bengaluru offers a promise of restoring village life, yet at the same time, their absence from the village disrupts the temporal and spatial rhythms that would otherwise inform quotidian life and its regeneration through ritual.

\section{Contingent presents}

Due to a lack of ritual time, set return dates, and intermittent wages, the families inhabited a contingent present, conceiving of and preparing for several possible scenarios simultaneously, and "standing by" (Kemmer and Simone 2021) a promise of return. Though Jonathan Parry argues the village takes on the quality of a waiting room between periods of work (2003), the city can similarly be viewed as a waiting room for those anticipating return to the village. While opportunities to dwell within the rural homestead are disrupted by the uncertainty of payment, opportunities to establish urban familiarity and rootedness are in turn disrupted by construction site residence. "We have no idea where we'll go after this gets 
over. We don't know even if we will get work somewhere or no," Lingamma told me as we sat in the family's hut one Sunday. In this way, urban residence has been continually punctuated by dislocation, particularly from ritual timespace.

When I asked about their unpaid wages, which had stalled the family's return for Ugadi, an important festival marking the new year, Lingamma replied, "They haven't given yet, otherwise we had planned to go to our village. They don't seem to give at all!' For the festival, the women and girls would make holige (sweet coconut flatbread), fruits, rice, and sambhar (a watery, lentil-based vegetable stew), but as I was reminded by Lingamma, "Here there's no way to make those things." To miss partaking in the auspicious festivities of Ugadi is to miss the ritual oil purification, the donning of new clothes, beginning new projects, and the sowing of crops. It denies the opportunity to herald the new year and renewal, iterating instead the unremarkable flatness of urban time experienced by those unable to partake in ritual. Living in Bengaluru thus had a destabilizing effect on the acknowledgement of ritual time itself. Hemavathi confirmed, "In Bangalore, we are completely unaware of festivals, we can't even realize Amavasya (the new moon day) here. But back in [the] village, we are aware of many festivals. There are different kinds of practices and poojas on every Amavasya days ... so many in fact!"

In her study of wonder in Bengaluru, Tulasi Srinivas argues that "the play of ritual time [...] juxtaposed with modern work time in Bangalore is a disarticulation of the present and part of a practical piety that allows for a melding of Hindu life with modern capitalist life" (2018, 3739). However, for those without temple access or the resources to acknowledge the necessary rituals of Ugadi and other similarly important festivals, such transformative potential, which Srinivas posits enables a break with the present and "the conditions for the possibility of wonderment and the delight of the interruption [of reality]" (ibid), is denied. Nevertheless, the memory, or indeed, the future promise of such possibility also holds transformative potential. To negotiate their interlinking states of material and temporal uncertainty, both families nurtured an enduring but fragmented connection with rural and ritual timespace, bridging necessary urban presents and desired village futures, an act Galam describes as a "technology of imagination" $(2019,590)$ through which uncertain futures are worked toward. Through this process of dislocation, the work of restoring ritual time is achieved by putting it on hold.

Interruptions to work were frequent, brought on by fluctuating sand prices and delayed shipments, or significantly, instigated by the families themselves in the event of nonpayment. "Sometimes I'm not able to pay them for almost two weeks, so I pay them one short. They're very flexible, so they understand," Praveen informed me. However, following overdue payment during Ugadi, the families downed tools, thus rejecting Praveen's objectification of them as uniformly "flexible," instead seeking work around the neighborhood. Nevertheless, such refusals were short-lived as Basappa, Hemavathi's husband, elaborated, saying, "again they'll convince us they'll give it [their pay] soon," even though this was often not the case. While the families could look for work in nearby locations, they were effectively bound by their unpaid wages and the fact they had few alternative forms of urban residence. This practice is common in the Indian construction industry - serving the purpose of retaining "footloose" workers by replacing historical systems of cash advance with payment in arrears (Breman 2016; Parry 2014). Though such actions are unquestionably oppressive and exploitative, they do not necessarily negate technologies of imagination, or the capacity of workers to critique conditions of exploitation. 


\section{Neither here nor there: gendered dislocations of the city?}

While the uneven syncopation of urban life was experienced by each family, their encounters (or lack thereof) with the social and physical cityscape produced distinctly gendered perceptions of Bengaluru. Through multi-sited research across Southeast Asia, Bunnell, Gillen, and Ho frame the city as a site of action for "prospecting the future" (2017). Attending to the shifting spatiotemporal locations of aspirations among migrant interlocutors, they conclude it was "the prospect of elsewhere - and of being elsewhere - that nurtures imaginings of aspirational futures and spurs efforts to realize them" (Bunnell, Gillen, and Ho, 2017:3). This was evidenced through the nostalgia and experiences of dislocation by the women and girls, whose desires were firmly rooted in the village, enabling them to endure the hardships and dislocating spacetime of the city.

Eramma and Rangamma recalled the perceived superiority of their village in numerous ways. Eramma, Lingamma's eight-year-old daughter, unhappily informed me of the disruption of rural routine that shaped her urban experience: "Back in the village, there would be school, and after coming back, some chores in the home, and then I would go out to play. There'd be so many children, a lot of friends, and all that. Here, I have only my family to keep company." Rangamma and Eramma would describe their favorite village festivals and all of the activities the children missed undertaking there: "We are made to wear special clothes and sit in our home, where we do pooja. We prepare delicacies. We stay up in the night, do the pooja, release arrows," said Rangamma, Hemavathi's daughter, a skinny girl of six. "What do you mean by releasing arrows?" I asked. Eramma responded, "It goes flying once you light it up. It's a firecracker, and like a rocket, it goes high into the air and bursts into a million colors. Like fireworks in the sky." Eramma and Rangamma demonstrated this further by running and making noises, mimicking the whizzes and small explosions. "Do you love to light up rockets?" I asked. Both girls nodded and Eramma gave a wistful sigh. "Hmm, yeah. Since there are no young boys in our family, I only light the firecrackers," she said. For Eramma and Rangamma, the village was a place to play, attend school, and participate in ritual time - a site of necessary recovery, recuperation, and festivities after long periods of urban hardship and exclusion (see also, Breman 2016). To be able to partake in these aspects of rural life, the families had to spend a great amount of time away from it. As Eramma confirmed, her family had been traveling between Bengaluru and Kurnool district for "many years," yet settling in the city was never discussed by the women or children.

Seeking to dispel western-centric constructs of teleological urbanization, James Ferguson stresses the impermanence of urban lives and how for some, the return to the village in lieu of adequate urban livelihood opportunities proves reluctant (1999). While this was the case for former migrants I knew, for cyclical migrant workers, sustainable residence in the village often was their aspiration. Even if this form of permanence was unachievable, they continually worked toward future return. For those with little to no land or socioeconomic capital to draw upon due to their caste and migrant status, fewer returns were possible. Subsequently, land ownership constituted a primary aspiration among the men on site (women were excluded from holding land), despite the chronic drought of the region. "If there's money left, and there's land available in my village, I would buy it," Basappa declared. Owning enough productive land presented an opportunity to spend more time in the village, although this remained dependent on the rains: "Only people with a lot of land go back when it rains, if it's a small patch of land, there's no point going back," Suraj said when I asked about returning during the monsoon. 
Though one could earn double in Bengaluru, continued drought and growing debt meant maintaining immediate familial life and the lives of dependents in the village presented an increasing challenge. Perhaps this is why Basappa entertained the idea of dwelling in both locations, informing me, "People back in our village only see money in denominations of hundreds, here there are five hundreds and thousands." He continued, "If our wives and kids are settled here [the city] we'll stay here." For Basappa, a desired home was not necessarily the village but where one's family might reside comfortably. At present, nether location fully fulfilled this criterion. Basappa and Hemavathi's differing opinions of the city were also informed by discrepancies in gendered mobility. In comparison to their wives' experiences, for Basappa and Suraj, the city was something of a known entity, albeit fragmented by the shifting localities in which the families lived and worked.

For Hemavathi, Lingamma, and their children, the known urban landscape extended to the end of the dusty lane of their present residence, the bus station where they arrived, and construction sites across the city. This may explain why neither could envision a future in Bengaluru, which remained both frightening and unfamiliar in their imaginations. Hemavathi and Lingamma seldom ventured out, having little idea of what lay beyond the changing building sites where they lived and worked. "The city is scary," Hemavathi once confided. The girls, too, were afraid to wander far: "Here, I go only to places I know, I don't stray anywhere. But in the village, I go out a bit farther," Rangamma informed me. As well as their frequently changing forms of workplace accommodation, this uncertainty was also instilled by the women's restricted movement in the urban milieu.

For Hemavathi and Lingamma, their exclusion from consumptive urban space, urban networks, and the ritual time of the village shaped their access to and sentiments toward Bengaluru. They primarily stayed on site working, looking after the children, and undertaking chores. In rare instances, they might travel to another site for work with their husbands. A typical day entailed getting up at dawn, fetching water, preparing food, and then beginning their labor on site. Such labors entailed digging, carrying headloads of bricks, mixing cement, sweeping, breaking stones, and assisting with the preparing and laying of thick concrete slabs. The girls took care of their younger siblings, although they were often unable to prevent the accidents and injuries that invariably befell young children and infants living on site. This lack of supervision was looked upon dimly by the surrounding residents and office workers. As a result, Hemavathi and Lingamma were made to feel unwelcome by the scrutinizing gaze of surrounding neighbors who threw their rubbish by their houses and scolded them for letting their children climb over the parked two-wheelers outside their huts. When I asked what Lingamma and Hemavathi did on their Sundays, when the men were at the market, Hemavathi, by now seven months pregnant, replied, "We rest a bit, cook, too. Not much. Working every day is also boring, right? After washing clothes, cleaning vessels, the next day after a ragi mudde (ball of millet) we again go back to work."

Basappa and Suraj, in comparison, while not exactly endowed with the same temporal and financial means to interact with the city as Baudelaire's flaneur-able to wander the city freely and discover its offerings - were familiar with the locality and public transport, having some time to loiter and drink after work. The men ventured out to a nearby market by bus on Sundays to buy food and to look for work. Sometimes they watched movies with the other men on the phone of Taj, a teenage plasterer, for a small fee. Significantly, Basappa and Suraj also received their wives' wages. Given that much of this was remitted back to the village, and the men purchased the families' food, Lingamma and Hemavathi had little access to money. 
While the men might go for cigarettes, tea, coffee, or arak (a local alcohol), for the women there was, as Hemavathi's answer suggested, little leisure time, save trying to recuperate from the strains of both their paid and unpaid labor. One humid Sunday afternoon, when she was resting in the hut, I asked Hemavathi if she liked the city. "Our village is better than here," she replied. The reason was simple enough: "Because it's our village. It's more like home, the surroundings, and all that." In a reversal of her husband Basappa's sentiments, she declared, "If we got our pay there [the village], we would happily live there." The wages required for lifecycle events, debt repayment, and crop sowing were only made possible by dislocation in Bengaluru, as Hemavathi reminded me: "We don't get salaries, we work in the fields and earn some money." "You can't grow enough just to stay in the village?" I asked. "No, there's no rains, so there's not enough rain now. We have to get the young ones married, we have to build houses, so we take loans, and then there's no savings, so we come here." Hemavathi's acceptance of these facts underlines a familial resolve and resilience in meeting these aspirational and practical needs, enabling families to repeatedly dislocate themselves from village life, despite the uncertainty and discomfort of urban labor.

Acknowledging James Scott's research on subaltern forms of resistance (1985), Pun Ngai and $\mathrm{Lu}$ Huilin claim that expressed nostalgia for the village amongst migrant workers "could be understood as a "weapon of the weak" (2010, 504), through which "Home' becomes their imaginary anchor to life" (ibid) - a rejection of the city in the face of its hostility and unknowability. Dislocation from the immediate and yet unknowable urban environment through nostalgia shielded both families, who did not know where they were headed to next within the city, or when. While the longing for home was a longing for familiarity and comfort (contra long-settled informants who frequently depicted the village as a place of hardship), it also enabled a productive absence from it, building a vision of desired futures composed from the fragments of interrupted rural dwelling. This act of nostalgic prefiguration, while bittersweet, allows families to endure the laborious urban present, drawing on the past to imagine future possibility.

Dislocation was practical in other ways, too, since the unsettled status of migrant workers keeps them in employment while local workers receive significantly less work. However, this does not mean migrant families accept all conditions their urban employers try to impose. For instance, accommodation had to at least be livable (although relative to an industry with incredibly low standards), as Lingamma attested: "The shed [residence] is inspected first. If it's habitable we'll go there." As this and the earlier example of the short-lived strike illustrates, while dislocation allowed the families to endure urban hardship, their willingness to accept exploitation had limits.

\section{The Urban Construction Site and Social Reproduction}

\section{Growing up on site: reproducing gendered work and workers}

The environment of the construction site shapes young bodies and minds, with the children who grow up on them often mimicking the roles of their parents in miniature. While they were officially not employed by Praveen or his maistri, the children performed minor tasks from the ages of around six onwards, graduating formally to construction labor in their early teens, although in broader contexts this invariably differs by site and familial circumstance. When I asked Rangamma, who sporadically attended school in the village, what she wanted 
to do, she replied with certainty: "This job only." For the girls, who were less likely to receive education, their futures appeared to inevitably hold gaare or coolie kelsa and agricultural work. Women could not rise to higher positions than these in either the village or the city. Since they are considered supplemental workers despite their considerable presence within the construction industry, they pull double labor, working in the home and on site. To Basappa, these forms of labor constituted wifely duty, rather than the women's roles as paid workers: "They [women] don't have much work back in the village, and if they don't come here, who's going to cook for us?"

For both families, the act of sending their children to school in Bengaluru was also impossible. "I would like to send them to school, but we'll need someone to pick them up and drop them [.] Our work sometimes goes on until eight in the evening," Basappa told me. It was Basappa's ambition that once Shiva, his son, was old enough, he would attend school in the village: "If we get them to study, they'll end up with good jobs; if we don't, or we pull them out of school too early, they'll end up doing the same work we're doing." Among local and migrant families, the education of boys remained prioritized, evidenced in this case by Rangamma, who had foregone school in the village where she might have stayed with extended kin to look after Shiva. In a scenario where girls continue to require dowries and leave their natal homes to join husbands, boys remain an ostensibly more practical form of investment due to their permanently embedded status within the family. While parents were able to focus on the most pressing needs of their children in conditions of scarcity, resource distribution was inherently gendered.

Should neither child enter sustained education, the boys might at least "be painters or carpenters or plumbers," Suraj informed me, though somewhat doubtfully. Indeed, were their sons to succeed in these areas, they would surpass their fathers, who still undertook gaare and coolie kelsa. To learn a trade, a worker had to find a tradesman willing to teach them, an action requiring enough social and financial capital to incentivize the tradesman in question. Since most informants from northern Karnataka and Andhra had not achieved this, their own networks remained insufficient to enable vocational growth (see also, RoyChowdhury 2014). Typically, trades were sought from northern states, resulting in regional and linguistic divisions between "unskilled" and skilled workers, stifling the opportunity for greater worker solidarity, and significantly for more local migrants, preventing the chance for learning on site.

Although Suraj hinted at the possibility of a trade for his son, the lack of alternative options for girls was inadvertently summed up by Hemavathi, who asked somewhat incredulously during a conversation about Rangamma, "What will she learn?" For Rangamma, girlhood formed a stepping stone to the world of work and marriage. Her apparent lack of commitment thus far to these interlinking forms of training was viewed dimly by her mother: "She's only good for dressing pretty and looking good, if you ask her to do any work, she's no good." Rangamma, a small girl with closely cropped hair like her mother's, lived in oversized handme-down T-shirts, often asking me for new clothes. Whether looking after Shiva, or assisting her pregnant mother, there was plenty to do for Rangamma on site. "She has plenty of time in her life to work," I naively replied. "Where I'm from, the kids have to be doing something, they'll be smart when they grow up if they do. If they're dull and don't do anything now, they'll grow up like that," Hemavathi responded. For Hemavathi, the kinds of aptitude she desired for her daughter did not necessarily apply to book smarts but rather skills centered around care-giving, farming, and construction work. 
In comparison to local women, who often expressed the desire for their children to move to other occupations, Hemavathi and Lingamma could not see their children moving beyond construction. Although the boys theoretically had a better chance than the girls at progression due to the structural inequalities of gender, the disparity created by living on site still widens the gulf between those with access to productive local networks and schools. Both the state and company owners may not intentionally be reproducing future workers by failing to facilitate access to schools in urban locales (they are only required to by law with the presence of fifty or more women workers on site), but this nevertheless remains a profitable by-product.

\section{Hidden and transgressive spaces of female labor}

The city is often stereotyped as a sexualized and corrupting space for women (Patel 2010; Phadke 2013), and for migrant populaces, the view from the village magnifies such imaginaries (Roy 2003; Dalmia 2012). Women's and girl's movement in such spaces may be socially and physically restricted or regulated by kin (Jatrana and Sangwan 2004; Patel 2010; Roy 2003), or themselves (Suri 2000). Such imaginaries are amplified on construction sites, perceived as transgressive and polluting spaces with the capacity to damage a family's honor. As Parry elucidates, "Lurid tales of sex on construction sites also suggest to many 'laborclass' people themselves (both male and female) that it is only 'loose' women who work on them" $(2014,1251)$. These entrenched views impede migrant women's mobility within and outside of their work, impacting not only freedom of movement but also their very chance of employment. According to Virender, a senior industry figure, "Typically the women are in the camps sometimes [when] the boys are not at work. I worry what will happen. This is the reason I keep the ladies to the bare minimum."

Leela Fernandes postulates that gender disparities are reproduced within public subaltern spheres, imposing the same bourgeois gender hierarchies in the workplace (1997). For female workers especially, these serve to reinforce their rank and status as informal labor-class, lowcaste women and "helpers." Sexual exploitation enforces class and caste hierarchies, placing women workers in a precarious position. Caste, but also class and intra-class distinctions, produce moral codifications of working women's bodies (Bear 2007; Gooptu and Chakravarty 2018; Parry 2014). On the site where Hemavathi and Lingamma worked, this division was intraclass; evidenced by the men working in trades who, usually better off and due to differing gender norms, seldom had wives with them. Indeed, Shambhulingappa, the site carpenter, was firm about this matter when I asked about his wife: "Does she go to work anywhere?" "No, she is a housewife. She stays in the home." When the conversation moved on, he interjected, emphasizing again that, "I don't send her anywhere else to work. Only I go to work, I feel it's enough." In this way, class and (invariably linked) caste markers on site are further reinforced - with those who can afford to keeping their womenfolk away.

For those without the requisite land or income, this separation is not possible. The currency of women's honor means stakes are high for female workers - especially resident migrant women. The Hindi-speaking men on site were especially subject to negative regional stereotypes by the southern workers, and Hemavathi and Lingamma claimed they frequently stared, avoiding their presence when possible. Given the language used about them by employers, and the hidden nature of sexual exploitation on site, it is unsurprising the majority of my female informants were reluctant to speak on this matter, refusing to fuel damaging stereotypes or rumors, which can result in domestic violence or even murder. Maistris, too, 
are often at the center of rumors concerning suspected sexual impropriety, further diminishing women's labor bargaining power and safety.

Though they enjoyed greater physical mobility in the village where both women worked in the fields, Hemavathi and Lingamma did not travel elsewhere or undertake other work. When I asked if they would consider alternative occupations, I was dismissed by Lingamma: "No one teaches like that back home. Back home they teach us how to work and how to farm." "But what if you could learn to do something else?" I asked. "If he [her husband Suraj] says, then I'll do it." Such gendered restrictions of mobility also extended to travel. When asked whether the women were able to ride a bike, Hemavathi replied, "They teach the men how to do all that because they need to travel for work." These patriarchal norms of mobility were reproduced in Bengaluru, where only the men would roam in the wider city searching for work. Hemavathi elaborated, "My husband searches for other buildings like this, under construction, and then enquires there for work. Every Sunday, when there isn't work, he goes in search, and if he finds the conditions favorable, they discuss the terms and money, and then come back."

While the provision of extra income was essential to the family in lieu of their unpaid Ugadi wages, since Hemavathi and Lingamma were never directly paid, their husbands effectively remained their labor brokers. By referring to their wives' work as a requisite of feminized caring duties and accepting their wages, Basappa and Suraj effectively made Hemavathi and Lingamma's labor invisible, conceptually transposing the surrounding construction site onto the domestic sphere of the village home. At the same time, however, Hemavathi herself had decided to work later into her pregnancy, despite Basappa's unease, revealing a contradictory balance between fiscal and bodily autonomy in modes of production and reproduction.

As discussed, contra depictions of the city as a site of greater freedom for rural women and girls (Dalmia 2012; Jagori 2004; Mills 1997), urban construction site residence frequently fails to offer such forms of mobility. The ability to move through the city and the construction industry is bifurcated by gender and age. Boys are more frequently able to stay back in the village with relatives and attend school, while their sisters assist with the raising of younger siblings in Bengaluru. As grown men, they might learn another trade in spite of the obstacles in finding a tradesperson willing to teach them. They also have the requisite freedom to become more familiar with the city over time, experiencing a taste of urban life and consumption beyond the dislocated space of construction site residence, in contrast to their female counterparts.

Sergei Shubin, in his analysis of migration and timespace, claims "a migrant can be seen as always situated and dwelling with others in the world, and yet never at home there as she is caught up and shares spatial and temporal structures not of her own choosing" (Hoy 2009, in Shubin 2015:352. Such spatial and temporal structures are inherently gendered, producing different outcomes in movement and progression. It is perhaps for these reasons that Hemavathi, Lingamma, Eramma, and Rangamma elected to inhabit the city in body only, undertaking an imaginative labor of dislocation while remaining excluded from any productive urban networks, subsequent resources, or opportunities they might avail during their punctuated residence in Bengaluru.

\section{Conclusion}


Observing the precarity generated by intersecting inequalities experienced in Bengaluru and my interlocutors' home district of Kurnool, I have shown how migrant families physically, temporally, and imaginatively engage with dislocation to work toward aspirations of village life, enabling continued returns to the city despite its discomforts. While the urban environ itself holds little aspirational currency for migrant families, its enduring ambivalence is not a by-product of exploitative employment practices (see De Haan 1999) but their intended effect - producing cheaper, captive, and yet permanently liminal workforces, with one foothold in Bengaluru and the other in their village. Dislocation is a product of and response to these practices.

Urban construction sites constitute an exemplar par excellence of the paradox and possibilities of temporospatial dislocation. They act as spaces of simultaneous presence and absence in the city, perpetuating intersectional reproductions of gendered, regional, and class inequality while serving as spaces of childrearing, nostalgia, and resilience. Through analysis of familial experiences of work and migration, I have illuminated how such entrenched inequality creates collective impediments to labor and lifetime mobilities, producing divergent forms of urban dislocation through differing experiences of consumption, movement, and care-giving.

In India, as in many countries, circular migration enables the continuation of life in otherwise unsustainable conditions while simultaneously contributing to instability. The overarching liminality of labor migration, though productive, demands sacrifice: the frequent if not total denial of education to children; the forfeiture of health, safety, and comfortable residence; and the heightened risk of sexual assault and exploitation. These visceral yet often invisible experiences of urban life recently informed the widely covered mass exodus of many of India's recent migrant workers during the pandemic. While many were adamant they would never return (Srivastava and Nagaraj 2020), the lack of viable options in the rural economy means the numbers of migrant workers are again swelling in Indian cities (Patnaik 2020). Exploring the ostensible contradictions of urban dislocation contextualizes and humanizes such headline-grabbing events.

Lived dislocation is both aspirational and disempowering, regenerative and destructive, daily and exceptional. Such interpretations of dislocation can therefore assist in further understanding how migrant workers respond to ongoing precarity in the cities in which they live and work, and in the rural homesteads they leave behind, uncovering aspirations that may otherwise be dismissed or remain hidden in scholarly accounts of migration and urbanity. For Hemavathi and Lingamma's families, dislocation constitutes an agentive attempt to prefigure fragmented timespace - enabling them to imagine and build toward a permanent village future as it continues to elude them.

\footnotetext{
Note

${ }^{1}$ The designated scheduled castes of India consist primarily of Dalits and OBC (Other Backward Castes). Dalits were previously considered "untouchable," and continue to face violence and discrimination across India. Like scheduled caste members, scheduled tribe members or Adivasis (India's indigenous population) suffer widespread discrimination and displacement from their land. Both groups are overrepresented in the most difficult and dangerous sectors of informal labor, including construction work, manual scavenging, and sewer cleaning.
}

\section{REFERENCES}


Action Aid (2017). "Invisible Work, Invisible Workers: The Sub-Economies of Unpaid and Paid Work: Action Research on Women's Unpaid Labour." Available online:

https://www.actionaidindia.org/publications/invisible-work [Last accessed: November 30 , 2018].

Agarwal, K. (2020, August 13 ${ }^{\text {th }}$ 2020). The Wire. India's Population Will be 1.52 Billion by 2036, With $70 \%$ of Increase in Urban Areas. Available online: https://thewire.in/government/indiapopulation-growth-government-report-2036-projections-urban-migration [Last accessed October 7th, 2021].

Allison, A. and C. Piot. (2014). Editors' Note on "Neoliberal Futures." Cultural Anthropology, 29 (1). Appadurai, A. (2013). The Future as Cultural Fact: Essays on the Global Condition. London: Verso.

(2004). "The Capacity to Aspire: Culture and the Terms of Recognition." In Culture and Public Action: A Cross-Disciplinary Dialogue on Development Policy, edited by V. Rao and M. Walton. Stanford: Stanford University Press.

Bangalore Mirror Bureau (2018, February 16 $\left.6^{\text {th }}\right)$. The Bangalore Mirror. "4 Dead, Many Trapped in Building Collapse in Kasavanahalli."

Available online: https:/bangaloremirror.indiatimes.com/bangalore/others/5-storied-deathtrap/articleshow/62937311.cms [Last accessed: September 5 , 2019].

Baruah, B. (2010). "Women and Globalisation: Challenges and Opportunities Facing Construction Workers in Contemporary India." Development in Practice, 20 (1): 31-44.

Bear, L. (2016). “Time as Technique.” Annual Review of Anthropology, 45: 487-502.

(2015). Navigating Austerity: Currents of Debt along a South Asian River. Stanford: Stanford

University Press.

(2007). Lines of the Nation: Indian Railway Workers, Bureaucracy, and the Intimate Historical Self. New York: Columbia University Press.

Bhalla, N. (2015). "Building India's Cities, Silent Workforce of Women goes Unrecognized." Reuters. Available online: https://www.reuters.com/article/us-india-women- construction/buildingindias-cities-silentworkforce-of-women-goes-unrecognized- idUSKBN0KL00920150112 [Last accessed: December 1, 2018].

Breman, J. (2016). On pauperism in present and past. New Delhi: Oxford University Press. (1996). Footloose Labour: Working in India's Informal Economy. Cambridge: Cambridge University Press.

Bunnell, T., J. Gillen, and E.L. Ho. (2017). "The Prospect of Elsewhere: Engaging the Future through Aspirations in Asia." Annals of the American Association of Geographers, 1-17

[DOI:10.1080/24694452.2017.1336424].

Crang, M. (2003) [2001]. "Rhythms of the City: Temporalised Space and Motion." In Timespace: Geographies of Temporality, edited by J. May and N. Thrift. London and New York: Routledge.

Chatterjee, P. (1993). The Nation and its Fragments. Princeton, NJ: Princeton University Press.

(1989). "Colonialism, Nationalism, and Colonialized Women: The Contest in India." American Ethnologist, 16 (4): 622-33.

Choudhury, T. (2013). "Experiences of Women as Workers: A Study of Construction Workers in Bangladesh." Construction Management and Economics, 31 (8): 883-98. 
Dalmia, A.J. (2012) "Strong Women, Weak Bodies, Muted Voices." Economic and Political Weekly, 47 (26-27): 249-55.

De Haan, A. (1999). “The Badli System in Industrial Labour Recruitment: Managers' and Workers' Strategies in Calcutta's Jute Industry.” Contributions to Indian Sociology, 33 (1-2): 272-301.

Deshpande, A. and N. Kabeer. (2019). (In)Visibility, Care and Cultural Barriers: The Size and Shape of Women's Work in India. Discussion papers series in Economics (DP No.04/19). Ashoka University, Department of Economics.

Devi, K. and U.V. Kiran. (2013). "Status of Female Workers in the Construction Industry in India: A Review." IOSR Journal of Humanities and Social Science, 14 (4): 27-30.

Dittrich, C. (2007). "Bangalore: Globalisation and Fragmentation in India's Hightech-Capital." ASIEN, 103 (April): 45-58.

Express News Service (2018, January $\left.13^{\text {th }}\right)$. The New Indian Express. "Andhra Pradesh: 44 per cent of school-going children in Kurnool underdeveloped." Available online: http://www.newindianexpress.com/states/andhra-pradesh/2018/jan/13/andhra-pradesh-44-per- centof-school-going-children-in-kurnool-underdeveloped-1752539.html [Last accessed: September 5 , 2019].

Ferguson, J. (1999). Expectations of Modernity: Myths and Meanings of Urban Life on the Zambian Copperbelt. Berkeley: University of California Press.

Fernandes, L. (1997). Producing Workers: The Politics of Gender, Class and Culture in the Calcutta Jute Mills. Philadelphia: University of Pennsylvania.

Galam, R.G. (2018). "Utility Manning: Young Filipino Men, Servitude and the Moral Economy of Becoming a Seafarer and Attaining Adulthood." Work, Employment and Society 33 (4):580-95.

Gamburd, R.M. (2004). "Money that Burns like Oil: A Sri Lankan Logic of Morality and Agency." Ethnology, 43 (2): 167-84.

Goldman, M. (2011). "Speculating on the Next 'World City."” In Worlding Cities, Asian Experiments and the Art of Being Global, edited by A. Roy and A. Ong. Blackwell Publishing.

Gopalan, K. (2010). "Torn in Two: The Tale of Two Bangalores Competing Discourses of Globalization and Localization in India's Informational City." Dharna: Bhavan's International Journal of Business, 4 (2): 83-103.

Gooptu, N. and R. Chakravarty. (2018). "Skill, Work and Gendered Identity in Contemporary India: The Business of Delivering Home-Cooked Food for Domestic Consumption." Journal of South Asian Development, 13 (3): 1-22.

Harms, E. (2013). "Eviction Time in the New Saigon: Temporalities of Displacement in the Rubble of Development." Cultural Anthropology, 28 (2): 344-68.

Institute for Human Development (2014). India Labour and Employment Report 2014: Workers in the Era of Globalization. New Delhi: Academic Foundation and Institute for Development.

Jackson, E. (2012). "Fixed in Mobility: Young Homeless People and the City." International Journal of Urban and Regional Research, 36 (4): 725-41. 
Jagori (2004). Rights and Vulnerabilities: A Research Study of Migrant Women Workers in the Informal Sector in Delhi. New Delhi: Jagori.

Jatrana, S. and K.S. Sangwan. (2004). "Living on Site: Health Experiences of Migrant Female Construction Workers." Asian and Pacific Migration Journal, 13 (1): 61-88.

Jeffrey, C. (2010). Timepass: Youth, Class and the Politics of Waiting in India. Stanford: Stanford University Press.

KCWU (2017). Personal Communication. KCWU city office, Bengaluru.

Kemmer, L, A. Simone. (2021). "Standing by the Promise: Acts of Anticipation in Rio and Jakarta." Environment and Planning D: Society and Space, January 2021. doi:10.1177/0263775820982997.

Khanijow, S. (2018, April 28 $\left.8^{\text {th }}\right)$. The Wire. "Why Women Construction Workers Will Continue to Deliver by the Roadside." Available online: https://thewire.in/women-construction-workers [Last accessed: December 1, 2018].

Khilnani, S. (2012). The Idea of India. London: Penguin Books Ltd.

Madhok, S. (2005). Report on the Status of Women in the Construction Industry. Available online:

http://ncw.nic.in/pdfreports/women \%20workers\%20in\%20construction\%20industry.pdf [Last accessed May 9, 2018).

May, J., and N. Thrift, eds. (2001). Timespace: Geographies of Temporality. London and New York: Routledge.

Mills, M.B. (1997). "Contesting the Margins of Modernity: Women, Migration and Consumption in Thailand.” American Ethnologist, 24 (1): 37-61.

Narain, P., S.D. Sharma, S.C. Rai, and V.K. Bhatia. (2009). "Inter-District Variation of Socioeconomic Development in Andhra Pradesh" Journal of Indian Social Agricultural Statistics, 63 (1): $35-42$.

Parry, J. (2014). "Sex, Bricks and Mortar: Constructing Class in a Central Indian Steel Town." Modern Asian Studies, 48 (5): 1242-75.

(2003). "Nehru's Dream and the Village 'Waiting Room': Long-Distance Labour Migrants to a Central Indian Steel Town.” Contributions to Indian Sociology, 37 (213): 217-49.

Patel, R. (2010). Working the Night Shift. Stanford: Stanford University Press.

Patel, R., and J. Pitroda. (2016). "The Role of Women in Construction Industry: An Indian Perspective." India Journal of Technical Education, Special Issue for ICWSTCSC (2016): 17-23.

Pattenden, J. (2012). "Migrating Between Rural Raichur and Boomtown Bangalore: Class Relations and Circulation of Labour in South India." Global Labour Journal, 3 (1): 163-90.

Patnaik, I. (2020, July $\left.19^{\text {th }}\right)$. The Economic Times. "Migrant Workers Slowly Returning to Cities; Locals Being Trained to Fill Immediate Gap. Available online:

https://economictimes.indiatimes.com/news/politics-and-nation/migrant-workers-slowly- returningto-cities-locals-being-trained-to-fill-immediate- 
gap/articleshow/77047814.cms?utm_source=contentofinterestandutm_medium=textandutm_ecampai gn=cppst [Last accessed: July 27,2020$]$.

Phadke, S. (2013). "Unfriendly Bodies Hostile Cities." Economic and Political Weekly, 48 (39): 50-9. Pederson, M.A. (2012). "A Day in the Cadillac: The Work of Hope in Urban Mongolia." Social

Analysis: Journal of Cultural and Social Practice 56: 2, 136-51.

Pun, N., and L. Huilin. (2010). "Unfinished Proletarianization: Self, Anger, and Class Action Among the Second Generation of Peasant-Workers in Present-Day China." Modern China, 36 (5): 493-519.

Ramsay, G. (2019). "Time and the Other in Crisis: How Anthropology Makes its Displaced Object." Anthropological Theory, 20 (4): 385-413.

Rao, M.M. (2019, August 14 , 2019). The Hindu. "Unsafe Construction Sites Prove Deathtraps for Bengaluru's Labourers.” Available online:

https://www.thehindu.com/news/cities/bangalore/unsafe-construction-sites-prove-deathtrapsth for-bengalurus-labourers/article29087474.ece [Last accessed: September 7 , 2019].

Reddy, D. S. R. (2018, November 29 $\left.{ }^{\text {th }}\right)$. The Deccan Chronicle. "Kurnool: Drought Drives Farmers from Fields to Metro Cities." Available online: https://www.deccanchronicle.com/nation/currentaffairs/291118/kurnool-drought-drive-farmers-from-fields-to-metro-cities.html [Last accessed: September 5 , 2019].

(2017, 26 ${ }^{\text {th }}$ March). The Deccan Chronicle. "Exodus as Drought Sets in on Kurnool." Available online: https://www.deccanchronicle.com/nation/current-affairs/260317/exodus-as-drought-sets-inon-kurnool.html [Last accessed: September 5 , 2019].

Roberts, N. (2016). To Be Cared For: The Power of Conversion and Foreignness of Belonging in a South Indian Slum. Berkeley: University of California Press.

Roy, A. (2003). City Requiem, Calcutta: Gender and the Politics of Poverty. Minneapolis: University of Minnesota Press.

RoyChowdhury, S. (2014). "New Paradigms of Labour Relations: How Much do They Explain?" ISEC, Bangalore, 1-32.

Salve, H. (2013, September 5 $\left.{ }^{\text {th }}\right)$. India Spend. "How India's Construction Workers Get Gypped of Their Due." Available online: http://archive.indiaspend/com/investigations/how-indias- constructionworkers-get-gyppedof-their-due-51414> [Last accessed: $2^{\text {nd }}$ December, 2018].

Scott, J. (1985). Weapons of the Weak: Everyday Forms of Peasant Resistance. New Haven: Yale University Press.

Shah, A., and J. Lerche. (2020). "Migration and the Invisible Economies of Care: Production, Social Reproduction and Seasonal Migrant Labour in India." Transactions of the Institute of British Geographers, 1-16. 
(2006). "The Labour of Love: Seasonal Migration from Jharkhand to the Brick Kilns of Other States in India." Contributions to Indian Sociology, 40 (1): 91-118.

Shubin, S. (2015). "Migration Timespaces: A Heideggerian Approach to Understanding the Mobile Being of Eastern Europeans in Scotland." Transactions of the Institute of British Geographers, 40: $350-61$.

Shruthi, H.M. (2017, December 31st). The Hindu. "Water at Sobha Construction Site Not Fit for Human Consumption: Officials." Available online: https://www.thehindu.com/news/cities/bangalore/water-at-sobha-construction-site-not-fit-for- humanconsumption-officials/article22339841.ece [Last accessed: September 25 , 2018].

Smith, C., and N. Pun. (2006). "The Dormitory Labour Regime in China as a Site for Control and Resistance." The International Journal of Human Resource Management, 17 (8): 1456-70.

Srinivas, T. (2018). The Cow in the Elevator: An Anthropology of Wonder. Durham: Duke University Press. Kindle Edition.

Sriramakrishnan, R. (2017). Personal Communication, Karnataka State Building and Other Construction Workers' Welfare Board, Bengaluru.

Srivastava, R.S., and A. Jha. (2016). Capital and Labour Standards in the Organised Construction Industry in India: A Study based on Fieldwork in the National Capital Region of Delhi. Project Report \#2, April. New Delhi: Centre for the Study of Regional Development, Jawaharlal Nehru University.

Srivastava, R.S., and A. Nagaraj. (2020, May 30 ${ }^{\text {th }}$ Scroll India. https://scroll.in/article/963251/i-willnever come-back-many-indian-migrant-workers-refuse-to-return-to-cities-post-lockdown [Last accessed: July 27,2020$]$.

Sudhakar, K.M. (2017). The New Indian Express. "Two Lakh Rural Poor Migrated from Andhra

Pradesh's Kurnool in Just Four Months. Available online:

http://www.newindianexpress.com/states/andhra-pradesh/2017/nov/09/two-lakh-rural-poor-

migrated-from-andhra-pradeshs-kurnool-in-just-four-months-1696180.html [Last accessed: September 29, 2019].

Suri, S. (2000). "Yellow Helmets: Worth and Work of Women Workers on Construction Sites in Northern India." Unpublished Master's thesis, Massachusetts Institute of Technology, Cambridge, MA.

United Nations, Department of Economic and Social Affairs/Population Division, (2029). World

Urbanization Prospects:The 2018 Revision. Available online:

https://population.un.org/wup/Publications/Files/WUP2018-Report.pdf [Last accessed:October 8, 2021].

Vaid, K.N, ed. (1999). Women in Construction. Mumbai: NICMAR Publication Bureau.

WIEGO (2004). "Women in India's Construction Industry.” Available online:

http://wiego.org/informal-economy/statistical-picture [Last accessed: March 16, 2019]. 
AUTHOR COPY: PLEASE DO NOT CIRCULATE UNTIL PUBLICATION [DEC 31 ${ }^{\text {ST }} 2021$ ] 